\title{
MEMUTUS MATA RANTAI \\ RADIKALISME DAN TERORISME BERBASIS STUDI ETNOPEDAGOGI DI PTNU DALAM MEMBENTUK KEBERAGAMAAN INKLUSIF DAN PLURALIS
}

\author{
Mukhibat \\ Sekolah Tinggi Agama Islam Negeri Ponorogo, Indonesia \\ E-mail: mukhibat@yahoo.co.id
}

\begin{abstract}
Education, including Islamic education, is one the fundamental instruments for nation and character building. The heterogeneity and plurality of social interactions, horizontally and vertically, need inclusive, tolerant and multicultural educational instruments. The term ethnopedagogy constitutes appropriate and relevant instrument to be developed in education as social and cultural reconstruction. In the context of Nahdlatul Ulama university or higher educational instutution (PTNU), the study of ethnopedagogy needs to be considered as a part of curriculum reform to produce the generation with inclusive, humanist and pluralist religiosity. This process will establish a perspective rooted in the variety of local epistemological framework in order to avoid streams that decrease national identity. The importance of respecting religious identity and different local cultures becomes the keyword of learning processes which correspond to students' experiences related to their life. Accordingly, the lecturers of PTNU should explore more contextual processes in learning so that the articulation of Islamic teachings as the content of learning for guiding students' life will not be out of context. The study of ethnopedagogy in turn will be able to cope with radicalism and terrorism and to face against formalism of some Islamic educational institutions that teach the puritanism of the Middle East.
\end{abstract}

Keywords: Ethnopedagogy; NU Higher Educational Instutution (PTNU), acculturative; local wisdom.

\section{Pendahuluan}

Sikap beragama ekslusif, intoleran, antipluralitas yang mengarah pada radikalisme dan terorisme, konflik antarras, agama, suku, dan 
golongan disebabkan karena manusia tidak mampu membangun hubungan yang harmonis dengan sesama, lingkungan, budaya, dan Tuhan. Hal ini menunjukkan belum maksimalnya peran pendidikan dalam menanamkan nilai-nilai kebaikan bersama yang diperlukan dalam bermasyarakat dan berbangsa. Pertanyaanya, kapan sikap keberagamaan tersebut akan berakhir? Tentu, hal ini sulit dipastikan. ${ }^{1}$ Artinya perang melawan radikalisme sudah memasuki kawasan yang lebih substantif, yakni tidak semata-mata konflik fisik, melainkan sudah memasuki kawasan konflik gagasan untuk merebut hati dan pikiran. Edward Said menyebutnya counter of terrorism. ${ }^{2}$

Membendung stigma Islam sebagai agama teroris dan menghilangkan citra Indonesia sebagai sarang teroris dapat dilakukan dengan menjalankan ajaran Islam secara inklusif-humanis sesuai kondisi lokalitas-kultural Islam Indonesia yang damai, sebagai agama rạ̣mah li al-álamîn. Penanganan radikalisme yang terlalu bertumpu pendekatan legal formal dan bersifat represif, yang selama ini dilakukan oleh pemerintah, perlu ditinjau ulang. Hal ini karena logika pendekatan melalui mekanisme hukum berlawanan dengan logika yang dianut oleh para teroris.

Pendidikan seharusnya menjadi salah satu instrumen fundamental sebagai media bagi pembentukan karakter bangsa (nation and character building) di tengah heterogenitas dan pluralitas yang menjadi karakteristik utama bangsa Indonesia. Di tengah banyak perbedaan tersebut, sebagai suatu kesatuan nasional agar integritas nasional tetap terjaga, perlu dibangun sikap inklusif, pluralis, toleran dan saling berdampingan dengan cinta dan perdamaian. Heterogenitas dan pluralitas dalam konteks interaksi sosial, baik secara horizontal maupun vertikal, tersebut membutuhkan instrumen pendidikan yang

\footnotetext{
${ }^{1}$ Dalam 14 tahun terakhir pemerintah dengan pendekatan legal formal dan bersifat represif sudah menangkap 1083 lebih tersangka teroris dan 75 lebih ditembak mati. Namun mereka terus ada di sekitar kita bahkan muncul jaringan baru. Lebih jauh, ternyata logika para teroris tidak seperti yang dibayangkan oleh sebagian besar orang, yakni dengan adanya penangkapan-penangkapan maka gerakan-gerakan tersebut akan berhenti. Sanksi pidana fisik tidak membuat pelaku berhenti, tetapi para teroris bertindak jauh melampaui rasa takut terhadap ancaman hukuman tersebut, dengan bukti sampai detik ini Indonesia belum bebas dari ancaman teroris. Hal ini juga menjadi bukti bahwa bangsa Indonesia dipastikan belum akan terbebas dari sikap beragama yang eksklusif, intoleran, antipluralitas yang mengarah pada radikalisme dan bahkan terorisme.

${ }^{2}$ Edward W. Said, The Mind of Terrorism (USA: Booksmaxwell, 2006), 24.
} 
berkarakter inklusif, toleran, dan plural. ${ }^{3}$ Pada konteks ini, terminologi pendidikan berbasis pada etnopedagogi menjadi istilah yang tepat dan relevan untuk dikembangkan dalam ranah pendidikan Indonesia sebagai bangsa yang plural.

Lantas bagaimana peran perguruan tinggi, terutama PTNU, dalam mengembangkan pendidikan yang berbasis pada studi etnopedagogi di atas? Studi etnopedagogi di PTNU dapat dilakukan pada rumpun mata kuliah pengembangan kepribadian (MPK). ${ }^{4}$ Etnopedagogi memandang pengetahuan lokal (local knowledge), atau yang lebih dikenal dengan kearifan lokal (local wisdom), sebagai sumber inovasi dan keterampilan yang dapat diberdayakan demi menciptakan dan membangun harmoni serta ketenteraman. ${ }^{5} \mathrm{Hal}$ ini karena, menurut Alwasilah, pendidikan adalah proses sosio-kultural yang akan mengantar anak menjunjung tinggi nilai-nilai kebersamaan, toleransi dan keberagaman. Dalam konteks kajian ini, etnopedagogi diposisikan sebagai social and cultural reconstruction melalui pedagogi pendidikan.

Muatan-muatan ajaran Islam seperti Islam rahmat bagi semua, toleransi, humanisme, pluralitas, dan multikulturalisme adalah di antara aspek-aspek yang harus menjadi perhatian para dosen, sehingga pendidikan tidak lagi bernuansa ideologis-politis. ${ }^{6}$ Selama ini, kenyataan praksis di lapangan, pembelajaran yang merupakan ujung tombak dan bagian dari proses membangun cara hidup pluralis dan humanis untuk memperkuat wawasan kebangsaan dan penghargaan akan keragaman, justru mulai kehilangan dimensi kulturalnya, bahkan kehilangan aktualisasinya karena terjebak pada penguasaan pengetahuan (knowledge) dengan membiarkan aspek afeksi (attitude) pendidikannya. Pembelajaran/perkuliahan pada umumnya dilakukan

3 Rodolfo Stavenhagen, Problems and Prospects of Multiethnic States (Tokyo: United Nations University Press, 1986), 21.

4 Standar kompetensi kelompok MPK yang wajib dikuasai mahasiswa meliputi pengetahuan tentang nilai-nilai agama, budaya, dan kewarganegaraan dan mampu menerapkan nilai-nilai tersebut dalam kehidupan sehari-hari; memiliki kepribadian yang mantap; berpikir kritis: bersikap rasional, etis, estetis, dan dinamis; berpandangan luas; dan bersikap demokratis yang berkeadaban. Lihat Keputusan Direktur Jenderal Pendidikan Tinggi Departemen Pendidikan Nasional Republik Indonesia Nomor: 43/DIKTI/Kep/2006 pasal 3.

5 A. Chaedar Alwasilah, dkk., Etnopedagogi: Landasan Praktik Pendidikan dan Pendidikan Guru (Bandung: Kiblat, 2009), 6.

6 Toto Suharto dan Ja'far Assagaf, "Membendung Arus Paham Keagamaan Radikal di Kalangan Mahasiswa PTNUN", al-Tahrir: Jurnal Pemikiran Islam, Vol 14, No. 1 (Mei 2014), 157. 
secara parsial dan tidak mengakomodir nilai-nilai toleransi, multikulturalisme, pluralitas dan kearifan lokal masyarakat setempat. Al-Qur'ân dan Hadîth yang menjadi muatan perkuliahan dipahami secara normatif tanpa melihat realitas plural sebagai bagian dari Islam. Aspek realitas dan historisitas dari Islam belum dikaji secara komprehensif, sehingga pemahaman terhadap berbagai aspek kehidupan cenderung fragmentatif dan eksklusif dan antirealitas plural. Padahal seharusnya perkuliahan, sebagai wahana pendidikan yang menanamkan plural society, dapat dikembangkan secara lebih sistematis dan komprehensif. Merenungkan kearifan lokal bukan berarti kembali ke masa lalu atau menjadi masyarakat tradisional lagi, namun mencari mutiara-mutiara para leluhur dan menjadikannya sebagai pegangan setiap langkah ke depan.

Mengingat begitu penting dan strategisnya studi etnopedagogi dalam pembangunan bangsa, maka kajian semacam ini yang memfokuskan masalah pengembangan studi etnopedagogi di PTNU sangatlah relevan. Harapannya adalah bahwa hasil studi semacam ini dapat menjadikan materi perkuliahan di PTNU sebagai instrumen penting dalam membentuk kehidupan yang harmonis penuh toleransi, dan inklusif-multikultural. ${ }^{7}$ Hal ini akan sejalan dengan historisitas pendidikan Islam yang selalu berdialog dengan budaya lokal yang melahirkan amaliah Islam Nusantara, dan sangat berbeda jika dibandingkan dari Islam yang berkembang di Timur Tengah atau dunia Islam lainnya. Rintisan dialog itulah yang kemudian telah mampu merajut kebersamaan untuk membangun sebuah kehidupan yang "humanis religius". ${ }^{8}$

Selain itu, permasalahan mendasar yang dihadapi adalah dosen di PTNU, salah satunya adalah kurangnya wawasan praktis serta terlalu teoretis dalam membahas Mata Kuliah Pengembangan Kepribadian (MPK) dan pembelajaran di kampus sehingga kekayaan tentang the wisdom of practice kurang maksimal. PTNU sejauh ini jarang mengkaji pola kontinuitas budaya belajar masyarakat Indonesia sehingga sebagian besar dosen bertaklid kepada pandangan budaya belajar bangsa lain. Hal inilah kiranya yang akan menjadi faktor penghambat

7 Lihat Komaruddin Hidayat dan Hendro Prasetyo, Problem dan Prospek IAIN: Ontologi Pendidikan Tinggi Islam (Jakarta: Ditbinperta Republik Indonesia, 2000).

8 Zurqoni dan Mukhibat, Menggali Islam Membumikan Pendidikan: Upaya Membuka Wawasan Keislaman dan Pemberdayaan Pendidikan Islam (Yogyakarta: Ar Ruzz Media, 2013), 132. 
produksi dan reproduksi budaya pendidikan karena dosen pada dasarnya berperan dalam memadukan antara teori dan praktik serta pemodelan. Intinya, jika kedua aspek tersebut lemah, maka kelemahan itu (dalam hal local wisdom budaya pendidikan), dalam perspektif etnopedagogi, pendidikan Islam akan terwariskan kepada dosen dan mahasiswa antar-generasi.

\section{Budaya dan Pedagogi: Persenyawaan Etnopedagogi}

Fenomena munculnya istilah etnopedagogi kiranya setara dengan munculnya varian dari istilah-istilah yang melekatkan kata pedagogi, misalnya ekopedagogi, etnofilosofis, etnopsikologi, etnomusikologi, etnopolitik dan sebagainya." Bagian ini bertujuan untuk menguji dimensi pedagogi melalui perspektif sosiologi pedagogi agar dapat memosisikan etnopedagogi di dalam disiplin pedagogi. Pembahasan diawali dengan keragaman konteks pedagogi di berbagai budaya yang mencerminkan hakikat dari pedagogi dan tren pengkajian terkait dengan pengembangan disiplin pedagogi itu sendiri.

Banyak yang menyangka bahwa istilah pedagogy merupakan istilah yang telah lama memiliki makna dan diterima secara luas terutama di budaya Anglo-Amerika ${ }^{10}$ sebagaimana di Amerika, Inggris dan Australia lebih mengenal dengan istilah didaktike dari pada pedagogy. Lingard (2010) mengomentari bahwa budaya pendidikan di Inggris pada saat itu belum mengedepankan nilai-nilai intelektual (bersifat anti-intellectual) sehingga belum memerlukan pedagogi sebagaimana kini sebagian besar komunitas pendidik, terutama di Eropa daratan. ${ }^{12}$

Kasus serapan istilah pedagogi tersebut mencerminkan bahwa makna pedagogy bersifat kontekstual yang memiliki pemaknaan yang berbeda dari berbagai budaya sekaligus menjadi bukti adanya hubungan erat antara pedagogi dengan kehidupan sosial budaya masyarakatnya. Hal ini mengingatkan pada pemikiran kolega saya dari Cambridge University, Prof. Robin Alexander, yang menegaskan hal tersebut melalui studi komparatif mengenai praktik pengajaran dan

\footnotetext{
${ }^{9}$ Alwasilah, dkk., Etnopedagogi, 4.

${ }^{10}$ Basil Berstein dan Joseph Solomon, "Pedagogy, Identity and the Construction of a Theory of Symbolic Control", British Journal of Sociology of Education, Vol. 20 (June 1999), 2.

${ }^{11}$ David Hamilton, "The Pedagogical Paradox (or Why No Didactics in England?)", Pedagogy, Culture and Society, Vol. 7 (1999), 133-152.

12 Bob Lingard, "Towards a Sociology of Pedagogies", makalah diseminarkan dalam $2^{\text {nd }}$ International Seminar 2010 'Practice Pedagogic in Global Education Perspective’ (Bandung: PGSD Universitas Pendidikan Indonesia, 17 Mei 2010).
} 
pembelajaran di lima negara. Dalam bukunya, Culture and Pedagogy, Alexander (2000) menemukan hubungan yang erat antara pedagogi dengan kehidupan sosial budaya masyarakatnya. Temuan Alexander sejalan dengan pandangan Bernstein yang menyatakan: How a society selects, classifies, distributes, transmits and evaluates the educational knowledge it considers to be public, reflects both the distribution of power and principles of social control. $^{13}$

Temuan tersebut mengukuhkan pandangan Bernstein (2004) yang memandang pedagogi, dalam hakikatnya sebagai cultural relay, sebagai a uniquely buman device for both production and reproduction of culture. Hal serupa dikemukakan oleh Bourdieu yang memandang pedagogi as necessarily involving power relations and as also central to the reproductive mechanism, in social structural terms, of schooling system. ${ }^{14}$ Selain itu, penelitian Alexander (2000) tersebut merepresentasikan definisi pedagogi secara luas yang berdasarkan pada aspek budaya melampaui konteks pengajaran di dalam kelas. Dalam hal ini, Alexander membedakan antara teaching dengan pedagogy. Menurutnya, Pedagogy is the art of teaching plus its associated discourse to do with learning, teaching, curriculum and much else. ${ }^{15}$ Pedagogi merupakan tindakan (teaching) dan wacana (discourse) sehingga pedagogy connects the apparently self-contained act of teaching with culture, structure and mechanisms of social control ${ }^{16}$ yang menjadikannya suatu bidang kajian yang kompleks.

Kiranya momentum wacana etnopedagogi semakin jelas konteksnya, jika mencermati perkembangan Lesson Study di Indonesia dalam satu dasawarsa terakhir. Istilah Lesson Study berasal dari kata jugyokenkyuu yang berarti pengkajian pembelajaran. Secara historis, Lesson Study telah berkembang di Jepang semenjak awal abad 20 dan kini telah menjadi subjek yang banyak didiskusikan dan dikembangkan di berbagai budaya. Perkembangan Lesson Study digunakan untuk menjelaskan bagaimana mengembangkan kerangka Etnopedagogi dalam pendidikan guru, sebagaimana Lesson Study kini banyak dikaji oleh para pendidik di dunia Barat.

Selanjutnya Alwasilah memandang bahwa pendidikan tidak terlepas dari aspek sosial dan kultural. Pendidikan bersifat deliberatif dalam arti masyarakat mentransmisikan dan mengabadikan gagasan

13 Berstein dan Solomon, "Pedagogy".

${ }^{14}$ Lingard, "Towards a Sociology of Pedagogies".

15 Robin Alexander, Culture and Pedagogy: International Comparisons in Primary Education (London: Blackwell, 2000).

${ }^{16}$ Ibid. 
kehidupan yang baik yang berasal dari kepercayaan masyarakat yang fundamental mengenai hakikat dunia, pengetahuan dan tata nilai. ${ }^{17}$ Etnopedagogi terkait erat dengan pendidikan multikultural. Pendidikan multikultural sendiri memuat perangkat kepercayaan yang memandang penting kearifan lokal dan keberagaman yang dimiliki komunitas etnis untuk membentuk gaya hidup, pengalaman sosial, identitas pribadi, dan kelompok sosial maupun negara. Etnopedagogi memandang pengetahuan atau kearifan lokal sebagai sumber inovasi dan keterampilan, dilanjutkan dengan pendidikan multikultural yang memberdayakan inovasi dan keterampilan itu agar dapat menyumbangkan masukan positif bagi kelompok sosial lain dan budaya nasional.

Sebagai sebuah kenyatan sejarah, agama dan kebudayaan dapat saling mempengaruhi karena di dalam keduanya terdapat nilai dan simbol. Agama adalah simbol yang melambangkan nilai ketaatan kepada Tuhan. Kebudayaan juga mengandung nilai dan simbol supaya manusia bisa hidup di dalamnya. Agama memerlukan sistem simbol. Dengan kata lain agama memerlukan budaya. Meskipun demikian keduanya perlu dibedakan. Agama adalah sesuatu yang final, universal, abadi (perenial) dan tidak mengenal perubahan (absolut). Sedangkan kebudayaan bersifat partikular, relatif dan temporer. Agama tanpa kebudayaan memang dapat bekembang sebagai agama pribadi, tetapi tanpa kebudayaan agama sebagai kolektivitas tidak akan mendapat tempat.

Di Jepang, etnopedagogi mendasari pengembangan dan praktik pendidikan guru. Sebagaimana dikemukakan oleh Shimara dan Sakai, etnopedagogi dikembangkan dari pengetahuan nilai budaya yang dimiliki guru dan nilai budaya dari proses mengajar, atau dapat dinyatakan integrasinya sebagai budaya pendidikan. ${ }^{18}$ Kedua nilai budaya tersebut dikemas ke dalam program pendidikan guru, dalam hal ini internship, yang bertujuan untuk memantapkan etnopedagogi baik sebagai ilmu (the science) maupun sebagai seni mengajar (the art of teaching). Hal ini menunjukkan bahwa pendidik di Jepang menganggap etnopedagogi secara utuh baik sebagai filosofi, teori, praktik dan kebijakan.

\footnotetext{
17 Alwasilah, dkk., Etnopedagogi, 16.

${ }^{18}$ Nobuo K. Shimahara dan Akira Sakai Nobuo K. Shimahara, "Teacher Internship and the Culture of Teaching in Japan", dalam Thomas Rohlen dan Christopher Bjork (eds.), Education and Training in Japan, Vol. 13, No. 2 (1998).
} 
Studi etnopedagogi tidak bisa lepas dari pribumisasi atau indigenisasi pendidikan. Indigenisasi merupakan instrumen kerja dari studi etnopedagogi, yakni sebagai upaya membangun perspektif yang lebih membumi atau berakar dari keragaman kerangka epistemologis lokal yang-oleh sebagian kalangan-dianggap primitif yang karenanya harus dihindari supaya kemurnian agama dan keyakinan tetap terjaga.

Secara akademis, para pakar telah melakukan klasifikasi indigenisasi/pribumisasi dalam berbagai lapangan atau disiplin keilmuan. Setidaknya terdapat empat level indigenisasi, yaitu: metateoretis (meta-theoretical), teoretis (theoretical), empiris (empirical), dan aplikasi (applied).$^{19}$ Pada level meta-teoretis, indigenisasi merujuk pada pengungkapan dan analisis pandangan dunia (worldview), ideologi, dan asumsi-asumsi filosofis yang memayungi ilmu-ilmu sosial dan produkproduknya. Pada tingkat teoretis, indigenisasi mengacu pada teori atau konsep yang dibangun dari pengalaman historis masyarakat pribumi yang telah dipraktikkan. Pada tingkat empiris, indigenisasi fokus untuk mengkaji masalah-masalah aktual yang dihadapi masyarakat, seperti, radikalisme, terorisme, tindakan destruktif, korupsi, dan imperialisme budaya. Pada level aplikasi, indigenisasi termanifes pada langkah spesifikasi kebijakan, program, dan solusi.

Dengan kerangka pikir di atas, studi etnopedagogi di PTNU menemukan relevansi yang kuat seiring dengan semakin menguatnya pula radikalisme dan terorisme dalam satu dekade terakhir yang memerlukan pemecahan berbasis bukti (evidence-based solution). Ilmuilmu kemanusiaan yang menjadi dasar pengembangan kepribadian mahasiswa memiliki peran sentral dalam penghayatan nilai-nilai kehidupan dan proyeksinya pada masa datang. Hal tersebut dikarenakan dalam konteks Indonesia sendiri etnopedagogi berasal dari perhatian para ahli pendidikan terhadap wacana budaya Nusantara. $^{20}$

\section{Pendidikan Islam Akulturatif}

Pendidikan dapat dinilai sebagai aktivitas kultural yang sangat khusus dan fundamental dalam kehidupan manusia, karena tanpa pendidikan sangat sulit kiranya sebuah kebudayaan atau perdaban dapat bertahan hidup apalagi berkembang maju. Kebudayaan tidak akan bisa survive jika tidak ditopang oleh berbagai instrumen

${ }^{19}$ Ibid.

${ }^{20}$ Alwasilah, dkk., Etnopedagogi, 24. 
pengembangan yang memungkinkanya ditransmisikan dari satu generasi ke generasi berikutnya. Secara sosiologis-antropologis, wajah Islam Nusantara merupakan hasil dari akulturasi nilai-nilai Islam yang universal dengan budaya lokal. ${ }^{21}$ Keterkaitan resiprokal antara pendidikan dan kebudayaan terlihat dari fungsi kultural pendidikan yang secara garis besar meliputi fungsi konservatif dan fungsi progresif.

Setidaknya pendidikan sebagai aktivitas kultural yang khusus dan fundamental bisa dijelaskan melalui dua perspektif. ${ }^{22}$ Pertama, perspektif historis menunjukkan bahwa pendidikan selalu menyertai pasang surut perjalanan sejarah umat manusia, dari coraknya yang sederhana dan tradisional hingga coraknya yang modern. Kedua, perspektif filosofis di mana karakteristik proses pendidikan mempunyai tiga sifat utama, yaitu tindakan performatif, tindakan reflektif, dan tindakan sadar tujuan.

Terkait dengan fungsi kultural pendidikan, sangatlah relevan melihat historisitas pesantren sebagai salah satu lembaga pendidikan Islam bercorak "pribumi" (indigenous) yang secara kultural merupakan sebuah lembaga pendidikan yang dilahirkan oleh budaya Indonesia, dan secara historis tidak sekadar mengandung makna keislaman, tapi juga makna keindonesiaan. Pesantren merupakan produk paripurna islamisasi Nusantara. Selain itu, pesantren juga sebagai pelestari budaya dan tradisi, baik tradisi keislaman maupun tradisi lokal. Ini artinya menempatkan pesantren sebagai pusat pendidikan yang sangat vital, bahkan sebenarnya peranan pendidikan pesantren melebihi peranan pendidikan formal dalam masyarakat di tengah krisis budaya dan karakter bangsa saat ini.

Kajian seputar eksistensi pesantren dalam kerangka pengembangan nilai budaya lokal dalam perkembangan global sekarang ini merupakan sesuatu yang dirasa makin penting. UndangUndang Sisdiknas No. 20 Tahun 2003 adalah "amunisi" baru pesantren yang memosisikannya setara dengan pendidikan lain. ${ }^{23}$ Kondisi ini sangat positif sekaligus tantangan bagi pesantren dalam mempertegas visi budaya lokalitasnya dalam konteks nasional dan

21 Hasani Ahmad Said, "Meneguhkan Kembali Tradisi-tradisi Pesantren di Nusantara", Jurnal Kebudayaan Islam Ibda', Vol. 9, No. 2 (Desember 2011), 181.

${ }^{22}$ Sa'îd Ismấîl 'Alî, al-Ușûl al-Thaqâfîyah li al-Tarbîyah (Kairo: Dar al-Salâmah, 2014), 33.

23 Ali Anwar, Pembaharuan Pendidikan di Pesantren Lirboyo Kediri (Yogyakarta: Pustaka Pelajar, 2010), 35. 
global. Harapannya adalah bahwa dengan kajian semacam ini akan menepis anggapan bahwa budaya lokal, apalagi modern, bukan menjadi musuh pesantren, melainkan menjadi pijakan bagi pesantren di Indonesia apakah ia seharusnya mengembangkan budaya Arab dan menghilangkan budayanya sendiri ataukah mengembangkan keduanya di atas basis keseimbangan dengan berpijak pada al-mu bâfazah 'alâ alqadìm al-sâliḥ wa al-akhdh bi al-jadîd al-așlạ̣? Selain itu, kajian ini juga sebagai bentuk kampanye akademik bahwa pesantren tidak mengajarkan radikalisme dan terorisme, namun pesantren memiliki tradisi dalam pengembangan kearifan lokal dan keindonesiaan yang konsisten ingin menciptakan insan humanis-religius.

Kajian ini juga relevan dengan paradigma baru yang diusung oleh Leif Manger yang melihat Islam bukan sebagai persoalan hitam putih, bukan persoalan tunggal, monopoli Timur Tengah, tetapi ia telah melakukan dialektika yang dinamis; antara Islam dalam kategori universal dengan lokalitas di mana ia hidup. Hal ini karena sekalipun Islam memiliki karakter universal, tapi Islam di Nusantara merupakan produk dari pergulatan dengan konteks lokal. Proses ini secara gradual berhasil mewujud dalam suatu tatanan kehidupan masyarakat santri yang saling damai berdampingan (peaceful coexistence) yang merupakan ciri utama filsafat Jawa yang menekankan kesatuan, stabilitas, keamanan, dan harmoni. ${ }^{24}$

Pendidikan pesantren tersebut mampu mempertahankan nilai-nilai (values system) yang diterapkan di pesantren itu sendiri, yaitu termasuk di dalamnya: pertama, prinsip tawassut yang berarti tidak memihak atau moderasi. Kedua, tawẫun, atau menjaga keseimbangan dan harmoni. Ketiga, tasâmuḅ atau toleransi. Keempat adalah sikap adil; dan kelima tashâwur atau prinsip musyawarah. "Pancasila" ala pesantren inilah yang nantinya menjadi bekal bagi para santri dalam proses bersosialisasi di masyarakat.

Eksistensi pesantren seperti yang tergambar di atas menjadikan masyarakat memandang dunia pesantren berwatak lemah lembut, karena sistem pendidikan model pesantren memiliki segudang nilainilai kearifan lokal (local wisdom) yang berupa tata aturan tidak tertulis yang menjadi acuan para santri dan masyarakat dalam berinteraksi, berkomunikasi antarindividu maupun kelompok secara harmonis dan

${ }^{24}$ Mukhibat, "Meneguhkan Kembali Budaya Pesantren dalam Merajut Lokalitas, Nasionalitas, dan Globalitas", KARSA: Jurnal Sosial dan Kebudayaan Islam, Vol. 23 No. 2 (Desember 2015), 178. 
damai. Selain itu, sistem pendidikan pesantren telah mampu mengarifi budaya lokal melalui pendekatan akulturatif-kontekstual. Dikatakan akulturatif-kontekstual karena sistem pendidikan pesantren lebih memilih bersanding daripada bertanding dengan budaya lokal. Dengan demikian, etnopedagogi harus menjadi landasan sekaligus koreksi dalam semua aspek tentang transfer pengetahuan antargenerasi adat tradisional melalui bentuk sarana dan metode pendidikan.

Oleh karena itu, menjadi sesuatu yang aneh apabila isu radikalisme dikaitkan dengan pesantren. Justru karakter seperti di ataslah yang merupakan karakter otentik pesantren, di mana sejak awal berdirinya ia menampilkan wajahnya yang toleran dan damai. Di pelosok-pelosok pedesaan Jawa, Sumatera, dan Kalimantan, banyak ditemukan performance pesantren yang berhasil melakukan dialog dengan budaya masyarakat setempat. Pesantren-pesantren yang ada di Jawa, terutama yang bermazhab Syafi'i dan memiliki hubungan dekat dengan Nahdlatul Ulama (NU) menampilkan sikap akomodasi yang seimbang dengan budaya setempat. Sehingga pesantren mengalami pembauran dengan masyarakat secara baik. Keberhasilan pesantren seperti ini kemudian menjadi model keberagamaan yang toleran di kalangan umat Islam pada umumnya. Tak heran, jika karakter Islam di Indonesia seringkali dipersepsikan sebagai Muslim yang ramah dan damai.

Berbeda dari agama-agama lain, Islam masuk ke Indonesia dengan cara yang elastis. Baik itu yang berhubungan dengan pengenalan simbol-simbol Islami (misalnya bentuk bangunan peribadatan) maupun ritus-ritus keagamaan (untuk memahami nilai-nilai Islam). Dapat dilihat, misalnya, masjid-masjid pertama yang dibangun di Indonesia—khususnya di Jawa—bentuknya menyerupai arsitektur lokal warisan dari Hindu, sehingga jelas Islam lebih toleran terhadap warna/corak budaya lokal. Tidak seperti, misalnya, Buddha yang masuk "membawa stupa", atau bangunan gereja Kristen yang arsitekturnya ala Barat. Dengan demikian, Islam yang datang di Indonesia tidak memindahkan simbol-simbol budaya yang ada di Timur Tengah (Arab) sebagai tempat kelahirannya. Demikian pula untuk memahami nilai-nilai Islam, para pendakwah Islam dahulu memiliki sikap dan sifat yang lebih luwes dan halus dalam menyampaikan ajaran Islam kepada masyarakat lokal yang telah mempraktikkan nilai dan budaya Hindu yang kuat. Sebagai eksemplar 
yang kuat dan sering disebut adalah apa yang dilakukan oleh para penyebar agama Islam di Jawa yang dikenal dengan sebutan Walisongo. Mereka dapat dengan mudah memasukkan Islam dan ajaran-ajarannya karena agama tersebut tidak dibawa dalam "bungkus" aslinya yaitu Arab, melainkan dalam racikan dan kemasan bercita rasa Jawa. Artinya, masyarakat diberi "bingkisan" yang dibungkus dalam budaya Jawa tetapi isinya Islam.

Oleh karena itu, merupakan hal penting bagi para ahli maupun praktisi pendidikan Islam membaca kembali nilai dan tradisi yang dimilikinya dalam pemaknaan yang lebih kreatif dan transformatif dalam rangka membentuk sikap peserta didik yang inklusif, humanis dan multikultural. Nilai-nilai kemandirian, kesetaraan, keadilan, solidaritas sosial, toleransi, keikhlasan, dan kesederhanaan apabila bisa ditranformasikan secara inovatif dengan studi etnopedagogi akan dapat melepaskan masyarakat dari dampak negatif globalisasi yang mendangkalkan karakter dan jati diri sebagai bangsa Indonesia.

Guna mencapai tujuan tersebut, nilai-nilai dasar yang selama ini menjadi rujukan pendidikan Islam perlu dikontekstualisasikan dengan kondisi kekinian. Pada titik ini, dialog antara tradisi (lokalitas) dan modernitas perlu dilakukan dalam konteks Indonesia (nasionalitas). Tuntutan kontekstualisasi ini untuk melawan formalisme yang dilakukan oleh sebagian sistem pendidikan Islam yang mengusung ideologi puritanisme ala Timur Tengah. ${ }^{25}$ Selain itu juga untuk membendung Westernisasi dan nilai-nilainya yang diusung oleh sebagian sistem pendidikan di Indonesia.

Sejatinya, Islam yang hadir di Indonesia memang tidak bisa dilepaskan dari tradisi atau budaya Indonesia. Sama seperti Islam di Arab Saudi, Arabisme dan Islamisme bergumul sedemikian rupa di kawasan tersebut sehingga kadang-kadang orang sulit membedakan mana yang merupakan nilai Islam dan mana yang merupakan simbol budaya Arab. Nabi Muhammad, tentu saja dengan bimbingan Allah (wa mâ yantiq 'an al-bawâ, in buwa illâ wahy yûhbâ), dengan sangat cerdas memahami sosiologi masyarakat Arab pada saat itu, sehingga beliau dengan serta merta menggunakan tradisi-tradisi Arab untuk mengembangkan Islam dan hal itu berhasil. Sebagai salah satu contoh adalah ketika Nabi hijrah ke Madinah, masyarakat Madinah di sana

${ }^{25}$ Lihat Aksin Wijaya, Menusantarakan Islam (Ponorogo: STAIN Ponorogo Press, 2011). 
menyambutnya dengan iringan gendang dan tabuhan sambil menyanyikan tala' al-badr 'alaynâ dan seterusnya.

\section{Peran PTNU dalam Membentuk Kehidupan Keberagamaan}

Perkembangan lembaga pendidikan Islam di Indonesia ditandai dengan keragaman. Keragaman tidak terletak hanya pada nomenklatur, tetapi juga pada tingkat yang lebih substantif seperti kurikulum, referensi, rujukan dan model pembelajaran yang diterapkan. Pendidikan Islam di Indonesia telah memiliki lembaga yang cukup lengkap mulai jenjang dasar hingga perguruan tinggi. Selain madrasah, pesantren, meunasah, dayah, rangkang, dan surau, lembaga pendidikan Islam yang telah berperan dalam dinamika pendidikan di Indonesia adalah Perguruan Tinggi Islam (PTI) yang dalam istilah terakhir disebut dengan Perguruan Tinggi Keagamaan Islam (PTKI) sesuai dengan PMA RI nomor 15 tahun 2014.

Kembali kepada isu terorisme dan radikalisme, sebagian besar orang tentu menduga bahwa hal-hal tersebut terkait dengan rendahnya tingkat pendidikan. Asumsi ini tidak selamanya benar, karena ternyata pada umumnya mereka (para teroris dan radikalis Muslim) adalah kaum terdidik di perguruan tinggi, terutama perguruan tinggi umum. Jika demikian, apakah ada yang salah dengan dunia pendidikan tinggi di Indonesia? PTKI merupakan lembaga yang sejak berdirinya mengajarkan ilmu-ilmu dan nilai-nilai keislaman. Oleh karena itu, dalam konteks teorisme dan radikalisme, jika ada alumninya yang terlibat dalam gerakan radikal, maka PTKI harus mengkaji ulang kurikulumnya. PTKI harus mampu menampilkan pemahaman agama yang inklusif dan humanis. Pemahaman terhadap ayat-ayat al-Qur'ân secara parsial dan normatif-tekstual tanpa melihat konteks dan realitas plural harus dirubah. Aspek realitas dan historisitas dari Islam harus dikaji secara mendalam, sehingga pemahaman mahasiswa terhadap berbagai aspek kehidupan tidak fragmentatif dan eksklusif.

Permintaan Menteri Agama RI kepada Rektor PTKIN untuk meningkatkan pengawasan terhadap kegiatan mahasiswa baik intra maupun ekstrakurikuler, misalnya, merupakan langkah yang tidak hanya patut diapresiasi tapi harus benar-benar ditindaklanjuti. Hal ini mengingat maraknya media yang sempat memberitakan tentang kasus pencucian otak (brain washing) terhadap beberapa mahasiswa PTKIN oleh gerakan Negara Islam Indonesia (NII). Bahkah ada beberapa 
mahasiswa alumni PTKIN yang diduga sebagai otak pelaku bom buku yang sempat menggegerkan masyarakat Ibu Kota.

Namun sejatinya, penulis meyakini bahwa kurikulum di PTKIN/PTKIS tidak ada yang mengajarkan radikalisme dan terorisme. Meskipun demikian himbauan sejumlah kalangan untuk mengadakan peninjauan kembali (review) terhadap kurikulum PTKI, hendaknya menjadi perhatian tersendiri bagi pengelola PTKI itu sendiri. Dalam penelitian yang penulis lakukan pada tahun 2009 di beberapa PTKIS di Yogyakarta, misalnya, diperoleh kesimpulan bahwa PTKI mempunyai peran besar dalam reproduksi dan deproduksi kurikulum dalam rangka deradikalisasi melalui mata kuliah. Mata kuliah dimaksud akan menawarkan berbagai pendekatan yang bisa dipakai oleh umat Islam untuk memahami ajaran agamanya, sehingga mereka tidak akan mudah terjebak dalam klaim kebenaran (truth claim) dalam ajaran agama hanya karena perbedaan pendekatan dalam mengkaji ajaran agama. Di sini, dosen pengampu mata kuliah dituntut untuk menjadikan mata kuliah sebagai ujung tombak dalam mengintegrasikan nilai-nilai pluralitas ke dalam proses pembelajaran. Jika ini dapat dilaksanakan di seluruh PTKI, baik negeri maupun swasta, maka seorang dosen telah berkontribusi dalam program deradikalisasi.

Pertanyaannya kemudian adalah apakah keterlibatan sejumlah mahasiswa maupun alumni PTKI itu berasal dari proses perkuliahan yang kurang mengintegrasikan nilai-nilai pluralitas? Banyak kalangan menduga bahwa gerakan-gerakan yang mengarah pada radikalisasi bukan disebabkan oleh kurikulum di PTKI, namun hal tersebut lebih disebabkan karena berkembangnya kelompok-kelompok (halâqah) pengajian yang berada, terutama, di masjid-masjid kampus. Menurut Ken Ward pengajian adalah sebuah inkubator bagi jihad. Pengajian menempati posisi strategis dalam berdakwah, dan selanjutnya perekrutan teroris. Pada tataran normatif, mendakwahkan agama, asalkan tidak dengan paksaan adalah sah, yang mengkhawatirkan apabila dakwah disertai provokasi kekerasan. ${ }^{26}$ Bagaimanapun dakwah/pengajian agama merupakan salah satu sarana bagi proses embodiment. Pengajian, ditambah dengan laku ritual tertentu, akan melahirkan habitus. Pengajian cara salat, misalnya, ditambah dengan

26 Robert W. Hefner, "Islamic School, Social Movements and Democracy in Indonesia", dalam Robert W. Hefner, Making Modern Moslem: the Politics of Islamic Education in Southeast Asia (Honolulu: University of Hawaii Press, 2009), 90. 
praktik salat itu sendiri, akan melahirkan habitus salat. Namun, cara salat adalah pilihan individu, boleh dilakukan secara berjemaah atau sendiri.

Fakta tentang adanya mahasiswa PTKIN yang menjadi eksponen organisasi Islam radikal dan bahkan mahasiswa dan alumninya menjadi pelaku aksi teror kemanusiaan, membuktikan bahwa gerakan radikalisme sudah menjadi semacam "arusutama" bagi sebagian kecil masyarakat dengan mendasarkan agama khususnya agama Islam bagi mereka yang Muslim. Persoalannya kemudian adalah bagaimana dakwah/pengajian seharusnya dilakukan oleh para pendakwah Muslim? Menurut hemat penulis, dakwah seharusnya dilakukan dalam rangka kontekstualisasi ajaran-ajaran Islam sesuai dengan latar belakang sosial dan kultural masyarakat Indonesia. Dakwah/pengajian juga perlu memperhatikan reorientasi motivasi dan redukasi terhadap pemahaman agama yang keliru tentang doktrin-doktrin keagamaan, termasuk jihad. Hal ini didasarkan pada kenyataan bahwa Islam yang hadir di Indonesia juga tidak bisa dilepaskan dari tradisi atau budaya Indonesia.

Kontektualisasi ajaran Islam, dalam hal ini, menjadi cara efektif untuk menanggulangi embodiment radikalisme dan terorisme di Indonesia. Kontekstualisasi ajaran tersebut dilakukan, antara lain, dengan menafsirkan Islam menurut basis kemanusiaan pada masa kekinian bukan zaman dahulu. Proses ini mensyaratkan keberanian untuk menginterpretasikan Islam dengan gagasan yang baru, dan bahkan-menurut penulis - tidak harus berkaitan dengan zaman Nabi Muhammad dahulu. Sebagai contoh adalah penggeseran makna jihad dari perang secara fisik dan frontal melawan musuh kepada pemaknaan yang lebih luas (generic), seperti upaya memajukan pendidikan umat Islam berbasis kemanusiaan.

Kontekstualisasi juga seharusnya dilakukan melalui proses reformasi kurikulum yang menyentuh lembaga pendidikan Islam, termasuk-dan terutama-pesantren yang selama ini dikaitkan oleh banyak kalangan memiliki hubungan dengan terorisme di Indonesia. Dalam konteks ini, tentunya, tidak semua kurikulum harus dihapus, melainkan hanya perlu semacam review, redesign, dan reorientasi terhadap isi kurikulum yang disinyalir berpotensi menimbulkan kebencian dan antipati di dalam diri peserta didik kepada orang atau kelompok lain. Sebaliknya, penting untuk diterapkan di dalam kurikulum tersebut nilai-nilai kebijakan dan kebajikan, seperti 
menghargai orang lain yang berbeda sekalipun. Dalam hal ini, politik kesalehan eksklusif harus dideproduksi menjadi politik kesalehan inklusif berbasis sosial yang responsif terhadap pelbagai masalah kemanusiaan.

Reformasi kurikulum tidak saja diperuntukkan bagi peserta didik, melainkan juga penting untuk menjangkau para pendidik (guru/ustaz). Pada tahun 2004 dan 2006, Robert Hefner misalnya, telah melakukan survei terhadap 940 guru/ustaz di madrasah-madrasah dan sekolahsekolah Islam modern di 8 propinsi di Indonesia. Dari jumlah tersebut, $85,9 \%$ responden bersepakat bahwa demokrasi adalah model pemerintahan terbaik di Indonesia. Namun pada saat yang sama $64,4 \%$ responden mendukung penerapan sharî́ah Islam yang dikampanyekan oleh organisasi-organisasi Muslim radikal, seperti NII, Laskar Jihad, dan Front Pembela Islam (FPI). ${ }^{27}$ Berdasarakan data ini, menurut hemat penulis, guru/ustaz adalah salah satu sasaran penting dari reformasi kurikulum pendidikan di Indonesia.

Khusus dalam bidang kehidupan keagamaan, terdapat sejumlah kecenderungan perubahan sosial yang perlu mendapatkan perhatian kalangan PTKI, di antaranya adalah masalah ekonomi masyarakat, tradisi atau kearifan lokal, forum komunikasi antarumat beragama, kemiskinan, dan kebodohan. PTNU-sebagai bagian dari PTKIdan sebagai lembaga pendidikan tinggi Islam milik NU jelas mempunyai kontribusi penting terhadap model keberagamaan masyarakat Muslim Indonesia. Berdasarkan ketentuan undang-undang yang ada disebutkan bahwa penyelenggaraan pendidikan tinggi dilaksanakan secara demokratis, berkeadilan, tidak diskriminatif, menjunjung tinggi HAM, nilai keagamaan, nilai kultural, dan kemajuan bangsa, sebagai satu kesatuan yang sistemik, diselenggarakan dengan sistem terbuka, multi makna dan dipandang sebagai suatu proses pembudayaan dan pemberdayaan peserta didik yang berlangsung sepanjang hayat. ${ }^{28}$

Studi Islam yang dikembangkan di PTKI, termasuk PTNUberlandaskan semangat undang-undang di atas-tidak hanya mendukung model keberagamaan inklusif di kalangan masyarakat Muslim Indonesia, lebih dari itu juga harus menciptakan kerukunan

\footnotetext{
27 Ibid.

28 Surat Keputusan Dirjen Dikti No. 43/Dikti/2006 tentang Rambu-rambu Pelaksanaan Mata Kuliah Pengembangan Kepribadian di Perguruan Tinggi (Jakarta: Dirjen Dikti-Depdiknas, Pasal 1 dan 2).
} 
antarumat beragama di Indonesia. Teologi inklusif, misalnya, dirintis perkembangannya oleh Harun Nasution dengan membuka mata kuliah Teologi Islam yang bercorak non-mazhab dan bersemangat toleran. Konsep ini selanjutnya dimatangkan oleh Nurcholis Madjid dalam berbagai tulisan dan ceramahnya. Hal ini jelas mensyaratkan bahwa semua kegiatan pendidikan Islam dituntut untuk memiliki kepekaan menghadapi masalah-masalah di atas. Pola indoktrinasi monokulturalisme yang dipaksakan selama ini perlu dievaluasi, karena telah terbukti berimplikasi negatif bagi rekonstruksi kebudayaan Indonesia yang plural. ${ }^{29}$

Secara kategoris, Pendidikan Islam dapat dilihat dalam dua perspektif, yaitu: pertama, sebagai proses pendidikan agama atau sebagai mata pelajaran di lembaga pendidikan; dan kedua, menunjuk pada sistem kelembagaan. Dalam tulisan ini, Pendidikan Agama Islam dimaksudkan dalam pengertian pertama, yaitu sebagai mata pelajaran yang proses pembelajarannya dilakukan dalam lembaga pendidikan. Sehingga pemanfaatan budaya lokal dalam Pendidikan Islam dimaksudkan sebagai pemanfaatan budaya lokal dalam pembelajaran Pendidikan Agama Islam di lembaga pendidikan. Oleh sebab itu, dalam aplikasinya, pemanfaatan budaya lokal dalam Pendidikan Islam dapat dilihat mulai dari pengembangan kurikulum sampai implementasi dalam pembelajaran.

Pemanfaatan budaya lokal dalam struktur kurikulum dapat mewujud dalam muatan lokal. ${ }^{30}$ Muatan lokal dirumuskan Badan Standar Nasional Pendidikan (BNSP) sebagai berikut:

Muatan lokal adalah kegiatan kurikuler untuk mengembangkan kompetensi yang disesuaikan dengan ciri khas dan potensi daerah, termasuk keunggulan daerah, yang materinya tidak sesuai menjadi bagian dari mata pelajaran lain dan atau terlalu banyak sehingga harus menjadi mata pelajaran tersendiri. Substansi muatan lokal ditentukan oleh satuan pendidikan, tidak terbatas pada mata pelajaran keterampilan. Muatan lokal merupakan mata pelajaran, sehingga satuan pendidikan harus mengembangkan Standar Kompetensi dan Kompetensi Dasar untuk setiap jenis muatan lokal yang diselenggarakan. Satuan pendidikan dapat menyelenggarakan satu mata pelajaran muatan lokal setiap

29 Akhmad Hidayatullah Al Arifin, "Implementasi Pendidikan Multikultural dalam Praksis Pendidikan di Indonesia", Jurnal Pembangunan Pendidikan: Fondasi dan Aplikasi, Vol. 1, No. 1 (Juni 2012), 56.

${ }^{30}$ Nana Sudjana, Pembinaan dan Pengembangan Kurikulum di Sekolah (Bandung: Sinar Baru Algesindo, 2005), 172. 
semester. Ini berarti bahwa dalam satu tahun satuan pendidikan dapat menyelenggarakan dua mata pelajaran muatan lokal. ${ }^{31}$

Dalam praktiknya, strategi pelaksanaan budaya lokal dapat dilakukan dengan tiga pendekatan, yaitu pendekatan monolitik, pendekatan integrasi dan pendekatan ekologis. ${ }^{32}$ Pemakaian pendekatan monolitik berimplikasi terhadap ketersediaan waktu khusus dalam kurikulum. Jika pendekatan ini yang dipakai, maka muncul nama mata kuliah baru sebagaimana dikehendaki dalam panduan penyusunan suatu kurikulum. Menurut BSNP kurikulum muatan lokal memiliki bobot setara dengan dua jam perminggu. Pendekatan integrasi dimaksudkan pembelajaran muatan lokal diintegrasikan dengan mata pelajaran lain atau mata pelajaran muatan lokal diberikan secara bersama dengan mata pelajaran lain. Dalam hal ini, Standar Kompetensi dan Kompetensi Dasar terintegrasi dalam mata pelajaran lain, sehingga muatan lokal menjadi suplemen terhadap mata pelajaran tersebut. Pendekatan ini dipergunakan jika materi muatan lokal berupa konsep atau prinsip yang sudah ada dalam mata pelajaran tertentu.

Sementara itu pendekatan ekologis dimaksudkan sebagai upaya pembelajaran materi muatan lokal dengan menggunakan lingkungan alam maupun sosial budaya setempat. Dalam pendekatan ini kondisi alam maupun sosial budaya dipelajari oleh pserta didik secara langsung. Secara praksis, jika dihubungkan dengan Pendidikan Agama Islam, maka dapat disusun program pembelajaran dengan mempergunakan dua pendekatan terakhir, yaitu integrasi dan ekologis. Proses pendekatan ini berhubungan dengan tingkatan pengalaman belajar manusia. Tingkatan belajar manusia dapat dibedakan menjadi tiga, yaitu pengalaman nyata (pengalaman dengan benda nyata), pengganti pengalaman nyata (benda atau media penampil benda nyata), dan pengalaman dengan kata-kata. Tingkatan ini memberikan pengaruh dalam proses belajar mengajar. Secara praksis, pendidik dihadapkan kepada permasalahan bagaimana melakukan proses belajar mengajar yang dapat memberikan efek positif bagi peserta didik.

Dengan kedua pendekatan tersebut, akan diketemukan dua fungsi, yaitu di satu sisi pembelajaran dapat memanfaatkan lingkungan sebagai upaya memberikan pengalaman nyata bagi peserta didik dan di

${ }^{31}$ PP. No. 19 Tahun 2005 tentang Standar Nasional Pendidikan.

32 Sudjana, Pembinaan, 177-178. 
sisi lain dapat mengintegrasikan pengetahuan yang diperoleh (baca: konsep sebagai ranah kognitif) dengan pengalaman nyata. Pengalaman nyata akan memberikan kesan yang lebih mendalam terhadap peserta didik daripada pengganti pengalalaman nyata apalagi pengalaman dengan kata-kata verbal. Pengalaman nyata akan memberikan efek, seperti kegiatan pembelajaran lebih menarik sehingga merangsang tumbuhnya motivasi.

Berdasarkan pendekatan di atas maka hakikat belajar lebih bermakna karena mahasiswa dihadapkan langsung dengan kenyataan. Bahan-bahan yang dipelajari lebih kaya dan beraneka ragam serta lebih faktual. Pembelajaran lebih aktif sebab mahasiswa langsung mempraktikkannya. Mahasiswa lebih memahami hakikat hidup yang ada di lingkungan sehingga tidak terasing dengan lingkungannya. Dalam praktiknya, ada sejumlah metode yang dapat dipergunakan dalam pemanfaatan lingkungan. Metode dimaksud adalah survei, karyawisata, praktik lapangan, berkemah, dan proyek pelayanan atau pengabdian. Survei dilakukan dengan cara peserta didik diajak mengunjungi lingkungan masyarakat setempat untuk mempelajari proses sosial. Kegiatan belajar dengan observasi, wawancara, dan studi dokumen. Karyawisata dilakukan dengan cara peserta didik keluar kelas untuk mempelajari objek tertentu di tempat-tempat wisata yang berhubungan dengan topik pembelajaran sehingga memiliki dua makna sekaligus, yaitu edukatif dan rekreatif. Praktik lapangan dilakukan dengan cara mahasiswa melakukan praktik di tempat tertentu yang berhubungan dengan keterampilan/kecakapan. Berkemah/out-bond dilakukan dengan cara peserta didik diajak masuk ke lingkungan alam atau lingkungan buatan tertentu untuk mempelajari suasana alam atau lingkungan buatan dengan cara merekam berbagai kondisi yang berada di dalamnya disertai aktivitas edukatif. Sedangkan proyek pelayanan/pengabdian masyarakat dilakukan dengan degan melakukan aktivitas pelayanan masyarakat, seperti penyuluhan, KKN, dan pemberian bantuan, sebagai implementasi pengetahuan yang dimiliki sekaligus memberikan manfaat konkret bagi masyarakat. ${ }^{33}$

Paparan di atas menunjukkan bahwa PTKI, terutama dalam konteks tulisan ini adalah PTNU, perlu melakukan kajian ulang secara periodik terhadap kurikulumnya. Muatan kurikulum secara filosofis

\footnotetext{
${ }^{33}$ Nana Sudjana dan Ahmad Rifai, Media Pengajaran (Bandung: Sinar Baru Algesindo, 2002), 210.
} 
dan substantif-pedagogis andragogis merupakan inti pendidikan untuk memfasilitasi perkembangan pribadi mahasiswa agar menjadi warga negara Indonesia yang religius, berkeadaban, berjiwa persatuan Indonesia, demokratis, bertanggung jawab, serta mampu hidup secara harmonis dalam konteks kemajemukan. ${ }^{34}$ Dalam konteks yang demikian, mendasarkan etnopedagogi dalam pengembangan kurikulum di PTNU memilik peranan yang sangat penting sebagai upaya mengembangkan masyarakat plural yang menghargai nilai-nilai budaya dan kearifan lokal. Hal ini telah dibuktikan oleh sistem pendidikan Islam model pesantren yang telah melahirkan nilai-nilai luhur seperti sikap dan perilaku santri yang tasâmuh, tawassut, dan tawẫun.

Beban PTNU diakui memang cukup berat. Namun jika tidak diupayakan dengan segera dan strategis maka citra Islam sebagai agama penabur kekerasan dan kebinasaan akan semakin kental, sehingga secara tidak langsung merongrong kewibawaan Islam sebagai agama rahmah li al-'alamîn akibat reduksi dari umat Islam sendiri yang sebenarnya sama sekali tidak mencerminkan representasi arusutama umat Islam Indonesia.

Pemahaman di atas secara otomatis telah mengakui universalitas al-Qur'ân (kulliyyat al-Qur'ân) yang menjadikannya kompatibel untuk diterapkan dalam berbagai kultur yang berbeda. ${ }^{35}$ Dalam konteks pola interaksi sinergis di sini, universalitas al-Qur'ân adalah puncak sekaligus tujuan yang dituju oleh kultur yang bergerak dari "bawah ke atas", yaitu dari partikularitas, lokalitas, dan berbagai kearifan lokal menuju idealisasi al-Qur'ân dalam ajaran-ajarannya yang dijadikan sumber dalam materi pendidikan Islam termasuk juga di PTNU. Kerangka pemikiran ini sangat sejalan dengan misi pembelajaran di PTNU yakni membantu mahasiswa memantapkan kepribadiannya agar secara konsisten mampu mewujudkan nilai-nilai dasar keagamaan dan kebudayaan, rasa kebangsaan dan cinta tanah air. Harapannya adalah bahwa mahasiswa mampun menerapkan kompetensi tersebut dalam kehidupan sehari-hari, yaitu memiliki kepribadian yang mantap,

34 U.S. Winataputra, Multikulturalisme-Bhineka Tunggal Ika dalam Perspektif Pendidikan Kewarganegaraan sebagai Wahana Pembangunan Karakter Bangsa Indonesia dalam Dialog Multikultural (Bandung: Sekolah Pascasarjana UPI, t.th.), 31.

35 Mahmud Arif, "Islam, Kearifan Lokal, dan Kontekstualisasi Pendidikan: Kelenturan, Siginifikansi, dan Implikasi Edukatifnya", Al-Tabrir: Jurnal Pemikiran Islam, Vol 15, No. 1 (2015), 130. 
humanis, berpikir kritis, bersikap rasional, dan bersikap demokratis yang berkeadaban.

Dalam rangka mencapai idealitas visi dan misi pendidikan berdasarkan etnopedagogi seperti di atas, maka PTNU setidaknya perlu melakukan beberapa alternatif perbaikan aktivitas pembelajarannya, di antaranya: pertama, dalam perspektif pengorganisasian materi pendidikan, selayaknya materi perkuliahan disusun berdasarkan asas kontinuitas, urutan dan integrasi. Kedua, dibutuhkan komitmen dari pendidik (dosen) untuk selalu bertukar informasi mengenai perkembangan model, pola, strategi pembelajaran sesuai dinamika perubahan sosial dan budaya. Ketiga, pembelajaran sebaiknya dikembangkan dalam format dan model yang terbuka sehingga tidak terkonsentrasi dalam penyampaian materi kognitif saja.

Adapun langkah-langkah konkret studi etnopedagogi yang dapat dikembangkan dalam perkuliahan pada MPK di antaranya: pertama, memberikan bekal nilai-nilai pluralitas, toleran, humanis, dan tidak indoktrinatif kepada seluruh dosen sebagai bagian yang tidak terpisahkan dari profesionalisme. Dalam langkah pertama ini kerangka etnopedagogi dalam pembelajaran di PTNU perlu memetakan prinsip dasarnya yaitu membangun hubungan insani yang luhur antara dosen dengan mahasiswa dalam rangka membangun pengetahuan dan budaya pendidikan yang memberdayakan. Dalam hal ini, penulis memetakan prinsip dasar tersebut menjadi dua level analisis: 1) aspek budaya (level makro); dan 2) aspek pengetahuan (level mikro). Level makro terkait dengan kepemimpinan PTNU dalam memelihara kemitraan dengan lembaga pendidikan Islam (aspek program), sementara level mikro secara umum menyangkut pengetahuan terkait dengan kurikulum, pengajaran dan pembelajaran serta konteks sosial budaya pendidikan (aspek konten dan proses). Isu utamanya terkait program pendidikan guru adalah keterkaitan antar-mata kuliah (connection) dan keterpaduan antara perkuliahan dan latihan praktik (coherence).

Kedua, pembelajaran dikembangkan dengan suasana yang menarik, dialogis, interaktif, dan terbuka dengan kajian etnopedagogi ke dalam kegiatan pengembangan diri. Ketika ini dilakukan dalam penyusunan desain pelaksanaan model unsur nilai-nilai kearifan lokal menjadi sesuatu yang menarik bagi mahasiswa untuk diresapi dan dilaksanakan dalam kehidupan sehari-hari. Ketiga, mengembangkan situasi lingkungan yang kondusif yang memungkinkan pendidikan 
yang berbasis pada budayanya sendiri bisa berkembang dalam pembelajaran di kampus. ${ }^{36}$

Tiga langkah tersebut di atas, semakin memperlihatkan hubungan yang jelas antara teori-praktik yang diajarkan secara sistematis, melalui pemodelan dan menyediakan kesempatan untuk mengkaji hubungan teori-praktik tersebut. Isu terkait dengan konten pendidikan Islam mencakup tiga pengetahuan dasar mengajar: 1) pengetahuan tentang mahasiswa dan bagaimana mereka belajar dan berkembang dalam konteks sosial/budaya tertentu; 2) pengetahuan tentang isi dan tujuan kurikulum dan bagaimana mengajarkannya; dan 3) pengetahuan tentang mengajar yang mempertimbangkan aspek konten dan mahasiswa, bagaimana mengembangkan situasi kelas yang produktif dan bagaimana melakukan penilaiannya. Adapun aspek proses menyangkut pedagogi di mana teridentifikasi prinsip-prinsip sebagai berikut: 1) mengintegrasikan antara teori dengan praktik yang mempertimbangkan pola budaya belajar masyarakat Indonesia; 2) menekankan analisis pemecahan permasalahan pengajaran dan pembelajaran (studi kasus, analisis video, praktik/observasi lapangan); 3) menyediakan kesempatan untuk merefleksikan pengajaran dan pembelajaran (log/jurnal, catatan refleksi, penelitian kelas); 4) membentuk iklim perkuliahan dari suatu komunitas belajar.

Analisis studi etnopedagogi rumpun MPK dapat dikerangkakan sebagai berikut:

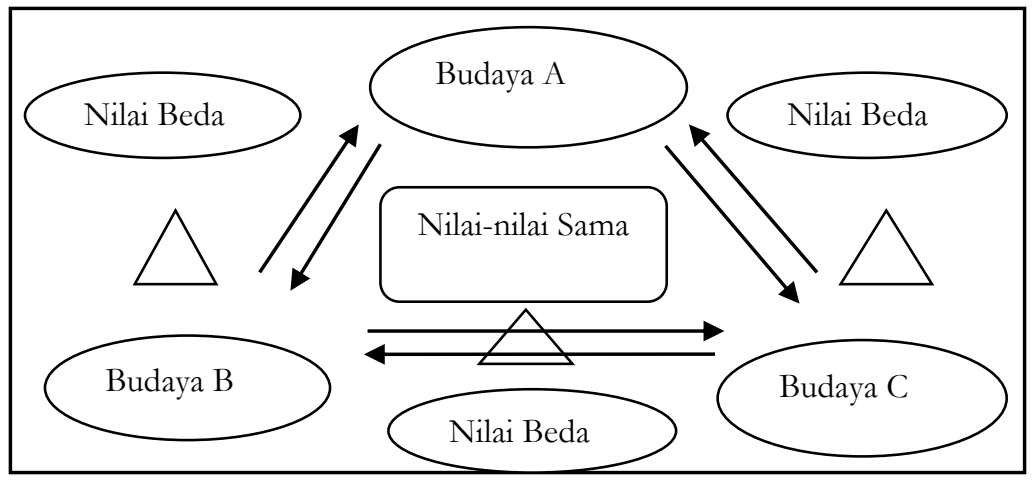

Proses pendidikan di atas menunjukkan adanya sadar budaya yang mengakui gagasan pentingnya penghargaan terhadap identitas agama dan budaya lokal yang berbeda, yang muaranya adalah sinkronisasi

${ }^{36}$ Colin Rose dan Malcolm J. Nicholl, Accelerated Learning for the 21st Century, terj. Dedi Ahimsa (Bandung: Nuansa, 2002), 37. 
pengalaman peserta didik dengan kebutuhan hidupnya. Di sinilah pendidik (dosen) harus mampu mengorkestrasi proses pembelajaran atau perkuliahan yang lebih kontekstual melalui studi etnopedagogi agar artikulasi ajaran-ajaran Islam yang menjadi muatan materi pembelajaran dalam memandu kehidupan peserta didik tidak lepaskonteks. Artinya, kebaikan/kebenaran sangat mungkin ditemukan di luar teks, di mana fungsi teks hanya tinggal mengafirmasinya.

Apabila situasi sadar budaya tersebut diupayakan lewat pendidikan, maka penyelenggaraan pendidikan harus memberikan ruang dan peluang bagi subjek-subjek yang terlibat di dalamnya untuk masuk ke dalam dan terlibat pada proses tertentu yang sifatnya dinamis. Artinya, hal itu menjadi sebuah proses yang memungkinkan adanya perubahan manusia. Jika hal ini bisa dilakukan, maka Indonesia akan memasuki situasi sadar budaya sebagaimana diidealisasikan. Persoalannya adalah nilai-nilai budaya yang manakah yang perlu menjadi perhatian utama dalam upaya menuju situasi sadar budaya itu? Dalam konteks pendidikan, nilai-nilai tersebut hingga kini masih menjadi perdebatan.

Dalam kaitan tersebut paling tidak terdapat dua macam pandangan. Pertama, adanya pemikiran yang mempertimbangkan kehidupan manusia yang makin mengglobal. Untuk itu, diharapkan akan terbentuk nilai-nilai budaya baru yang bersifat mondial, transnasional, atau pranata nilai budaya yang berada pada mainstream kehidupan di dunia ini. Nilai-nilai budaya tersebut dijadikan acuan dan tolok ukur yang dapat diterapkan di mana-mana. Kedua, adanya pemikiran yang bertolak dari kekhawatiran munculnya dampak budaya yang disebabkan oleh globalisasi, terutama sekali, tata ekonomi dan tata informasi. Pemikiran kedua ini mewaspadai berbagai akibat yang mungkin timbul dan tidak menguntungkan bagi wilayah-wilayah kehidupan yang tidak berada di jalur utama. Mereka yang tetap menghayati nilai-nilai budaya lokalnya dikhawatirkan akan menjadi kaum marginal yang kurang dimunculkan dalam konstelasi informasi dunia, dan seringkali kurang diuntungkan secara material. Oleh karena itu, upaya untuk mendudukkan jati diri bangsa, yang ditandai oleh kebudayaannya, akhirnya menjadi isu kemanusiaan yang bersifat sentral.

Etnopedagogi harus menjadi pemeran utama dalam semua aspek tentang transfer pengetahuan antargenerasi adat tradisional melalui bentuk sarana dan metode pendidikan. Studi etnopedagogi bertujuan, 
antara lain, untuk pembentukan keterampilan mahasiswa agar akuisisi kearifan lokal dapat disinkronisasi dengan pelbagai isu sosial dengan pendekatan berbasis masyarakat (society-based approach). Dalam konteks ini, diperlukan pengakuan terhadap hak-hak akademik dosen dan mahasiswa untuk mengetahuinya dalam rangka untuk menghidupkan dan melindungi serta mengembangkan budaya sendiri. Oleh karena itu, kepemimpinan dalam lingkup PTNU harus mengoptimalkan kebijakan desentralisasi pendidikan. Pimpinan dan semua elemen PTNU harus mengakomodasi aspek berharga kearifan lokal serta harus dapat mengembangkan sensitivitas terhadap kearifan lokal tersebut sebagai bentuk penghormatan pada identitas budaya, toleransi antarbudaya, pengembangan sikap budaya yang responsif, peningkatan kemampuan akademik, peningkatan pengetahuan mengenai kemajemukan kebudayaan, peningkatan kemampuan analisis dan interpretasi perilaku kultural, dan peningkatan kesadaran kritis tentang kebudayaannya sendiri.

\section{Penutup}

Studi etnopedagogi pada dasarnya merupakan kontekstualisasi ajaran Islam dan menjadi salah satu cara efektif untuk menanggulangi embodiment radikalisme dan terorisme dan-pada yang samamelahirkan sikap keberagamaan inklusif, humanis dan pluralis. Kontekstualisasi ajaran Islam dilakukan dengan upaya menafsirkan kembali Islam menurut basis kemanusiaan yang dilakukan melalui proses reformasi kurikulum di PTNU sehingga politik kesalehan eksklusif dapat dideproduksi menjadi politik kesalehan inklusif berbasis sosial, budaya, lingkungan yang responsif terhadap berbagai masalah kemanusiaan. Inilah, barangkali menurut penulis, salah satu alasan terkuat kenapa Indonesia memiliki peluang besar menjadi center of excellent bagi studi pendidikan Islam di dunia.

Hal penting lain yang harus diperhatikan adalah bahwa keberhasilan studi etnopedagogi di PTNU sangat tergantung pada halhal sebagai berikut: pertama, pengorganisasian materi pendidikan, materi perkuliahan harus disusun berdasarkan asas kontinuitas, urutan dan integrasi. Kedua, komitmen dari pendidik (dosen) untuk selalu bertukar informasi mengenai perkembangan model, pola, strategi pembelajaran sesuai dinamika perubahan sosial dan budaya. Ketiga, pembelajaran dalam format dan model yang terbuka sehingga tidak terkonsentrasi dalam penyampaian materi kognitif saja. Dengan demikian meniscayakan bahwa etnopedagogi memerlukan dukungan 
kebijakan dan kebajikan kepemimpinan pendidikan agar gagasan etnopedagogi tidak menjadi suatu retorika belaka.

\section{Daftar Rujukan}

Alexander, Robin. Culture and Pedagogy: International Comparisons in Primary Education. London: Blackwell, 2000.

'Alî, Saî̀d Ismâîl. al-Usûul al-Thaqâfîyah li al-Tarbîyah. Kairo: Dar alSalâmah, 2014.

Alwasilah, A. Chaedar dkk. Etnopedagogi: Landasan Praktik Pendidikan dan Pendidikan Guru. Bandung: Kiblat, 2009.

Anwar, Ali. Pembaharuan Pendidikan di Pesantren Lirboyo Kediri. Yogyakarta: Pustaka Pelajar, 2010.

Arif, Mahmud. "Islam, Kearifan Lokal, dan Kontekstualisasi Pendidikan: Kelenturan, Siginifikansi, dan Implikasi Edukatifnya", Al-Tabrir: Jurnal Pemikiran Islam, Vol 15, No. 1, 2015.

Arifin, Akhmad Hidayatullah Al. "Implementasi Pendidikan Multikultural dalam Praksis Pendidikan Di Indonesia", Jurnal Pembangunan Pendidikan: Fondasi dan Aplikasi, Vol. 1, No. 1, Juni 2012.

Berstein, Basil dan Solomon, Joseph. "Pedagogy, Identity and the Construction of a Theory of Symbolic Control", British Journal of Sociology of Education, Vol. 20, June 1999.

Hamilton, David. "The Pedagogical Paradox (or Why No Didactics in England?)", Pedagogy, Culture and Society, Vol. 7, 1999.

Hefner, Robert W. "Islamic School, Social Movements and Democracy in Indonesia", dalam Robert W. Hefner, Making Modern Moeslem: the Politics of Islamic Education in Southeast Asia. Honolulu: Univerity of Hawai Press, 2009.

Hidayat, Komaruddin dan Hendro Prasetyo. Problem dan Prospek IAIN: Ontologi Pendidikan Tinggi Islam. Jakarta: Ditbinperta Republik Indonesia, 2000.

Lingard, Bob. "Towards a Sociology of Pedagogies" makalah diseminarkan dalam $2^{\text {nd }}$ International Seminar 2010 'Practice Pedagogic in Global Education Perspective'. PGSD Universitas Pendidikan Indonesia Bandung, 17 Mei 2010.

Mukhibat. "Meneguhkan Kembali Budaya Pesantren dalam Merajut Lokalitas, Nasionalitas, dan Globalitas", KARSA: Jurnal Sosial dan Kebudayaan Islam, Vol. 23 No. 2, Desember 2015.

Rose, Colin dan Malcolm J Nicholl. Accelerated Learning for the 21st Century, terj. Dedi Ahimsa. Bandung: Nuansa, 2002. 
Said, Edward W. The Mind of Terrorism. USA: Booksmaxwell, 2006.

Said, Hasani Ahmad. "Meneguhkan Kembali Tradisi-tradisi Pesantren di Nusantara", Jurnal Kebudayaan Islam Ibda', Vol. 9, No. 2, Desember 2011.

Shimahara, Nobuo K. dan Akira Sakai Nobuo K. Shimahara. "Teacher Internship and the Culture of Teaching in Japan", dalam Thomas Rohlen dan Christopher Bjork (eds.), Education and Training in Japan, Vol. 13, No. 2, 1998.

Stavenhagen, Rodolfo. Problems and Prospects of Multiethnic States. Tokyo: United Nations University Press, 1986.

Sudjana, Nana dan Ahmad Rifai. Media Pengajaran. Bandung: Sinar Baru Algesindo, 2002.

Sudjana, Nana. Pembinaan dan Pengembangan Kurikulum di Sekolah. Bandung: Sinar Baru Algesindo, 2005.

Suharto, Toto dan Ja'far Assagaf. "Membendung Arus Paham Keagamaan Radikal di Kalangan Mahasiswa PTNUN", al-Tabrir: Jurnal Pemikiran Islam, Vol 14, No. 1, Mei 2014.

Wijaya, Aksin. Menusantarakan Islam. Ponorogo: STAIN Ponorogo Press, 2011.

Winataputra, U.S. Multikulturalisme-Bhineka Tunggal Ika dalam Perspektif Pendidikan Kewarganegaraan sebagai Wabana Pembangunan Karakter Bangsa Indonesia dalam Dialog Multikultural. Bandung: Sekolah Pascasarjana UPI, t.th.

Zurqoni dan Mukhibat. Menggali Islam Membumikan Pendidikan: Upaya Membuka Wawasan Keislaman dan Pemberdayaan Pendidikan Islam. Yogyakarta: Ar Ruzz Media, 2013. 